Vol. 1 No. 4 November 2021 e-ISSN : 2775-2593 | p-ISSN : 2775-2585

\title{
PENINGKATAN KEAKTIFAN DAN HASIL BELAJAR PKn MELALUI MODEL PEMBELAJARAN KOOPERATIF JIGSAW
}

\author{
RATNANINGSIH \\ SMP Negeri 2 Adimulyo \\ e-mail: ratnaningsih.hmc@ gmail.com
}

\begin{abstract}
ABSTRAK
Metode yang diterapkan guru dalam pembelajaran PKn masih bersifat konvensional, cenderung menggunakan metode ceramah yang verbalistik, sehingga mengakibatkan siswa pasif, kurang bersemangat, dan hasil belajar siswa rendah. Untuk memperbaiki proses dan hasil belajar disikapi guru dengan menerapkan model pembelajaran kooperatif Jigsaw dan mengaplikasikannya dalam bentuk Penelitian Tindakan Kelas (PTK). Tujuan Penelitian Tindakan Kelas ini yaitu untuk meningkatkan keaktifan dan hasil belajar PKn. Tindakan dilaksanakan melalui tiga siklus. Setiap siklus meliputi empat kegiatan yaitu (1) Perencanaan (Planning), (2) Pelaksanaan (Acting), (3) Pengamatan (Observing), dan (4) Refleksi (Reflection). Satu siklus dilaksanakan dalam dua sampai tiga kali pertemuan. Berdasarkan hasil análisis data, temuan, dan pembahasan yang telah dilakukan dapat disimpulkan bahwa tindakan yang dilakukan pada kelas VIIIA untuk meningkatkan keaktifan dan hasil belajar PKn melalui model pembelajaran kooperatif Jigsaw berhasil karena indikator kinerja penelitian terpenuhi. Sebelum tindakan dengan menggunakan model pembelajaran kooperatif Jigsaw, keaktifan siswa kelas VIIIA sebesar 73.43 dalam katagori aktif dan pada akhir siklus III sebesar 79.10 dalam katagori sangat aktif, meningkat sebesar 5.67 (meningkat 8\%). Sebelum dilakukan tindakan ketercapaian KKM pada kelas tersebut adalah 10\%, setelah tindakan siklus I menjadi $54.33 \%$ (meningkat $43.33 \%$ ), setelah tindakan siklus II menjadi $76.67 \%$ (meningkat $23.34 \%$ dari siklus I), dan setelah tindakan siklus III meningkat menjadi $93.33 \%$ (meningkat $16.66 \%$ dari siklus II).
\end{abstract}

Kata Kunci: Keaktifan, Hasil Belajar, Model Pembelajaran Kooperatif Jigsaw.

ABSTRACT

The method applied by the teacher in Civics learning is still conventional, tends to use the verbalistic lecture method, resulting in passive students, lack of enthusiasm, and low student learning outcomes. To improve the learning process and results, the teacher responded by applying the Jigsaw cooperative learning model and applying it in the form of Classroom Action Research (CAR). The purpose of this Classroom Action Research is to increase the activeness and learning outcomes of Civics. The action is carried out through three cycles. Each cycle includes four activities, namely (1) Planning, (2) Acting, (3) Observing, and (4) Reflection. One cycle is carried out in two to three meetings. Based on the results of data analysis, findings, and discussions that have been carried out, it can be concluded that the actions taken in class VIIIA to increase the activity and learning outcomes of Civics through the Jigsaw cooperative learning model were successful because the research performance indicators were met. Before the action using the Jigsaw cooperative learning model, the activeness of class VIIIA students was 73.43 in the active category and at the end of the third cycle of 79.10 in the very active category, an increase of 5.67 (an increase of 8\%). Before the action, the KKM achievement in the class was $10 \%$, after the first cycle of action it became $54.33 \%$ (an increase of $43.33 \%$ ), after the second cycle of action it became $76.67 \%$ (an increase of $23.34 \%$ from the first cycle), and after the third cycle of action it increased to $93.33 \%$ (an increase of $16.66 \%$ from cycle II).

Keywords: Activity, Learning Outcomes, Jigsaw Cooperative Learning Model.

\section{PENDAHULUAN}

Guru yang profesional seperti yang diamanatkan dalam Undang-Undang Nomor 5 Tahun 2005 tentang Guru dan Dosen adalah guru yang menguasai kompetensi paedagogik, profesional, kepribadian, dan sosial. Kompetensi paedagogik adalah kemampuan guru dalam 


\section{Vol. 1 No. 4 November 2021 e-ISSN : 2775-2593 | p-ISSN : 2775-2585}

mengelola pembelajaran yang meliputi pemahaman terhadap peserta didik, perencanaan dan pelaksanaan pembelajaran, evaluasi hasil belajar, dan pengembangan peserta didik untuk mengaktualisasikan berbagai potensi yang dimilikinya. Dengan demikian guru yang menguasai kompetensi paedagogik, akan mampu menciptakan suasana pembelajaran yang kondusif, kreatif, efektif, inovatif, dan menyenangkan, sehingga mampu mengembangkan potensi peserta didiknya secara optimal.

Akan tetap berdasarkan pengalaman peneliti, selama ini proses pembelajaran PKn masih bersifat konvensional. Proses pembelajaran masih berpusat pada guru (teacher oriented). Guru mendominasi pembelajaran dengan metode ceramah yang verbalistik, kurang variatif dalam menggunakan metode, media atau alat peraga, sehingga sikap siswa cenderung pasif, kurang bersemangat, kurang termotivasi dalam mengikuti pelajaran dan kurang memiliki rasa tanggungjawab terhadap tugas yang diberikan oleh guru. Proses pembelajaran yang demikian sangat menghambat kreativitas dan aktivitas belajar siswa, yang pada akhirnya menyebabkan hasil belajar PKn tidak optimal.

Hasil belajar yang tidak optimal ini, tampak jelas pada kelas VIIIA. Hasil belajar siswa kelas VIIIA pada mata pelajaran PKn masih jauh dari dari kriteria ketuntasan minimal yang ditetapkan, yaitu 75. Berdasarkan hasil pre-test dari 30 orang siswa yang dapat mencapai ketuntasan belajar hanya tiga orang atau sekitar 10\%, sedangkan yang belum mencapai KKM sejumlah 27 orang (90\%), dan nilai rata-rata kelas baru mencapai 52.33.

Keadaan tersebut jika dibiarkan akan berdampak yang kurang baik terhadap pencapaian mutu pendidikan, khususnya mutu Pendidikan Kewarganegaraan. Untuk mengatasi permasalahan tersebut, maka perlu dilakukan penelitian tindakan kelas tentang penggunaan model pembelajaran yang menarik, kooperatif, interaktif dan menyenangkan sehingga dapat meningkatkan keaktifan dan hasil belajar siswa. Salah satunya menggunakan model pembelajaran kooperatif Jigsaw.

Menurut Lie dalam Rusman (2011:218), pembelajaran kooperatif model Jigsaw merupakan model pembelajaran kooperatif dengan cara siswa belajar dalam kelompok kecil yang terdiri dari empat sampai enam orang secara heterogen dan siswa bekerja sama saling ketergantungan positif dan bertanggungjawab secara mandiri.

Banyak riset yang telah dilakukan berkaitan dengan pembelajaran kooperatif Jigsaw, secara konsisten menunjukkan bahwa siswa yang terlibat aktif dalam pembelajaran kooperatif Jigsaw ini memperoleh prestasi belajar lebih baik, mempunyai sikap yang lebih baik dan positif terhadap pembelajaran, disamping saling menghargai perbedaan dan pendapat orang lain.

Beberapa penelitian yang relevan yang telah dilakukan diantaranya adalah penelitian Rio Septiadi dengan judul "Upaya Peningkatan Aktivitas Siswa dalam Pembelajaran Kooperatif Jigsaw di SMP Negeri 1 Kota Singkarak", dengan hasil bahwa dengan menggunakan Model pembelajaran kooperatif Jigsaw dapat meningkatkan aktivitas siswa. Selain itu penelitian Sutopo dengan judul "Upaya Peningkatan Hasil Belajar Fisika Siswa Kelas IX Melalui Pembelajaran Kooperatif Tipe Jigsaw Di SMP Negeri 1 Singgahan”. Hasil penelitian tersebut menunjukkan adanya peningkatan aktivitas siswa yang diikuti oleh peningkatan prestasi belajar siswa, serta munculnya ketrampilan kooperatif siswa dalam kegiatan pembelajaran.

Berdasarkan latar belakang tersebut di atas, maka peneliti memilih judul "Upaya Meningkatkan Keaktifan dan Hasil Belajar PKn Melalui Model Pembelajaran Kooperatif Jigsaw. Dengan penelitian ini diharapkan bahwa proses pembelajaran PKn dengan mengunakan model pembelajaran kooperatif Jigsaw akan menyenangkan, kreatif, dapat meningkatkan keaktifan dan hasil belajar yang optimal.

\section{METODE PENELITIAN}

Penelitian ini menggunakan metode Penelitian Tindakan Kelas (PTK). Subjek penelitian ini adalah siswa kelas VIII A yang berjumlah 30 orang terdiri atas 20 orang laki-laki 
dan 10 orang perempuan. Penelitian ini dilaksanakan pada mata pelajaran PKn materi tentang Memahami Kedaulatan rakyat dalam Sistem Pemerintahan Indonesia.

Jenis data dalam penelitian ini terdiri dari: (1) Data kuantitatif, berasal dari data hasil penilaian pre test, ulangan harian siklus I, siklus II, dan siklus III, (2) Data kualitatif, teriri dari: (a) Hasil rekapitulasi angket dan observasi keaktifan belajar siswa, (b) RPP siklus I, siklus II, dan siklus III, dan (c) Foto-foto dokumentasi yang mendukung penelitian ini. Pengumpulan data dilakukan dengan teknik tes dan non tes. Teknik tes digunakan untuk mengukur veriabel hasil belajar, yang antara lain dilakukan dengan cara pre-test pada kondisi awal, tes ulangan haría pada akhir siklus I, II, dan III. Sedangkan teknik non tes digunakan untuk mengukur variabel keaktifan belajar antara lain cara memberi angket (kuesioner), dan lembar observasi keaktifan belajar siswa.

Teknik yang digunakan untuk memeriksa validitas data adalah teknik analiytic triangulation, yaitu suatu cara untuk mendapatkan keakuratan data dengan menggunakan berbagai cara/prosedur/metode agar data yang diperoleh dapat dipercaya kebenarannya. Langkah ini ditempuh dengan pengamatan (observasi), angket (kuisoner), dan pengambilan gambar dalam bentuk foto. Teknik análisis data yang digunakan adalah teknik análisis deskriptif komparatif (statistik deskriptif komparatif) untuk menganalisis data-data kuantitatif, yaitu dengan membandingkan nilai pre-tes, nilai tes setelah siklus I, II, dan III serta membandingkan skor keaktifan belajar siswa pada kondisi awal dengan skor pada akhir siklus.

Kriteria keberhasilan penelitian ini adalah sebagai berikut: (1) Hasil belajar meningkat jika: (a) Nilai rerata kelas meningkat dari kondisi awal dan atau dari siklus ke siklus dan skor individu juga meningkat dari siklus ke siklus, (b) Secara klasikal 85\% siswa mencapai nilai sama dengan/dan atau di atas KKM 75 pada akhir siklus. (2) Keaktifan belajar meningkat, jika terjadi perubahan dari kondisi awal yang kurang aktif, menjadi aktif, atau sangat aktif atau dari kriteria yang sama dengan adanya peningkatan skor dari siklus ke siklus.

\section{HASIL DAN PEMBAHASAN}

\section{Hasil}

\section{A. Deskripsi Data Kondisi Awal}

1. Deskripsi Keaktifan Belajar Siswa

Data kondisi awal keaktifan belajar siswa kelas VIIIA sebelum dilaksanakan pembelajaran dengan menggunakan model kooperatif Jigsaw diperoleh dari penyebaran angket, yang setelah dianalisis hasilnya dapat dilihat pada tabel 1 berikut ini.

\section{Tabel 1. Data Keaktifan Belajar Pada Kondisi Awal}

\begin{tabular}{ccccc}
\hline Uraian & K.1 & K.2 & Jumlah & $\begin{array}{c}\text { Rata- } \\
\text { Rata }\end{array}$ \\
\hline Jumlah & 2203 & & & \\
Rata-rata & 73.43 & & & \\
\hline
\end{tabular}

Dari tabel 1 tersebut di atas menunjukkan bahwa keaktifan belajar siswa pada kondisi awal termasuk dalam katagori aktif. Namun demikian peneliti masih memandang perlu untuk ditingkatkan lagi, sebab berdasarkan pengamatan peneliti dengan tingkat keaktifan yang sudah tinggi tersebut belum berdampak positif pada peningkatan hasil belajar. Selain itu ada beberapa indikator keaktifan yang perlu ditingkatkan lagi seperti keberanian bertanya, kemampuan menyampaikan pendapat, dan kemampuan bekerjasama.

2. Deskripsi Hasil Belajar Siswa

Data hasil belajar pada kondisi awal diperoleh dari penilaian pre-test sebelum pembelajaran menggunakan model pembelajaran kooperatif Jigsaw. Setelah dianalisis hasil belajar tersebut dapat dilihat pada tabel 2 berikut ini.

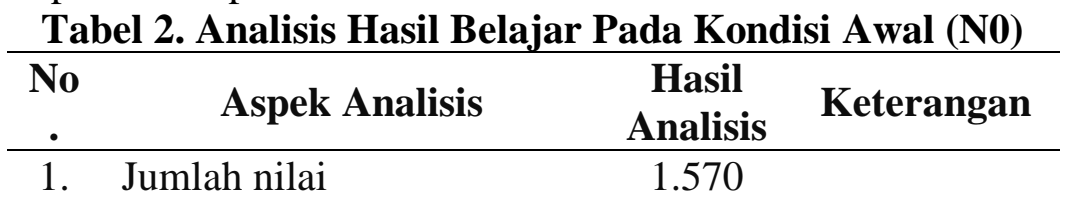


Vol. 1 No. 4 November 2021 e-ISSN : 2775-2593 | p-ISSN : 2775-2585

2. Nilai tertinggi

3. Nilai terendah

4. Rata-rata

5. Daya serap

6. Stándar deviasi

7. Ketuntasan belajar

8. Jumlah siswa yang tuntas

9.
90

30

52.33 Belum tuntas

$52.33 \%$ Belum tuntas

16.95

9.38\% Belum tuntas

27

Dari tabel 2 tersebut menunjukkan bahwa hasil belajar siswa kelas VIIIA pada materi Menjelaskan Makna Kedaulatan Rakyat masih tergolong rendah. Kondisi yang demikian menjadi bahan renungan bagi peneliti untuk menyusun perencanaan pembelajaran yang dapat mengaktifkan dan mengoptimalkan hasil belajar siswa. Setelah berdiskusi dengan teman sejawat, peneliti berencana akan memperbaiki proses dan hasil pembelajaran dengan menggunakan model kooperatif Jigsaw pada siklus I.

\section{B. Deskripsi Data Hasil Siklus I}

1. Perencanaan Tindakan (Planning)

Pada tahap ini peneliti melakukan kegiatan sebagai berikut.

a. Merancang RPP dengan menggunakan model pembelajaran kooperatif Jigsaw tipe Alliot Aronson, dkk.

b. Membuat instrumen penelitian untuk mengukur keaktifan siswa berupa lembar observasi, pedoman penilaian, dan alat pendokumentasian kegiatan.

c. Membuat instrumen penilaian hasil belajar berupa kisi-kisi, lembar soal ulangan harian siklus I, kunci jawaban dan pedoman penilaian.

d. Menyiapkan lembar kerja kelompok serta alat dan bahan lain yang diperlukan dalam penelitian ini.

2. Pelaksanaan Tindakan (Acting)

Proses pembelajaran pada siklus I merupakan pembelajaran pada materi Memahami Kedaulatan Rakyat dalam Sistem Pemerintahan di Indonesia, khususnya pada materi tentang Menjelaskan Makna Kedaulatan Rakyat, yang dilaksanakan selama dua kali pertemuan (4 x 40 menit). Pada siklus I proses pembelajaran menggunakan model kooperatif Jigsaw yang dikembangkan oleh Ellliot Aronson, dkk dengan tahap-tahap seperti berikut ini.

a. Kegiatan Pendahuluan

1) Apersepsi : guru membuka pembelajaran dengan meminta ketua kelas untuk memimpin doa, mengecek kehadiran siswa, kebersihan kelas, dan alat kelengkapan belajar.

2) Motivasi: antara lain dilakukan dengan memberikan pertanyaan-pertanyaan pendahuluan yang berkaitan dengan materi pembelajaran, dan menyampaikan tujuan pembelajaran.

b. Kegiatan Inti

1) Siswa mendengarkan penjelasan guru tentang Makna Kedaulatan Rakyat.

2) Siswa mendengarkan penjelasan guru tentang langkah-langkah pembelajaran menggunakan model kooperatif Jigsaw tipe Alliot Aronson, dkk.

3) Pembentukan kelompok asal yang beranggotakan lima orang secara heterogen.

4) Setiap kelompok asal mendapat materi/masalah yang harus diselesaikan.

5) Setiap kelompok mempelajari materidan menyelesaikan masalah yang ditugaskan.

6) Setiap anggota kelompok asal bertemu dengan anggota kelompok asal lain membentuk kelompok ahli untuk berdiskusi membahas permasalahan yang sama. 
Vol. 1 No. 4 November 2021 e-ISSN : 2775-2593 | p-ISSN : 2775-2585

7) Setiap anggota kelompok ahli kembali ke kelompok asal dan bertugas mengajarkan materi yang telah dipelajari dalam kelompok ahli.

8) Presentasi kelompok ahli dalam diskusi kelas.

9) Guru memberikan penguatan tentang materi yang telah didiskusikan.

c. Kegiatan Penutup

1) Guru membimbing siswa untuk membuat kesimpulan tentang materi yang telah didiskusikan.

2) Guru memberikan evaluasi hasil belajar dengan menggunakan tes ulangan harian.

3) Guru memberikan predikat dan penghargaan terhadap kelompok.

4) Guru melakukan refleksi dengan meminta siswa mengungkapkan kesan tentang penggunaan model koopertaif Jigsaw dalam proses pembelajaran.

5) Guru memberi tugas berkaitan dengan materi yang akan dipelajari dalam pertemuan berikutnya.

6) Guru menutup pembelajaran dengan berdoa yang dipimpin oleh ketua kelas.

3. Pengamatan Tindakan (Observing)

a. Data Pengamatan Keaktifan

Pengamatan (observasi) keaktifan siswa pada proses pembelajaran siklus I ditekankan pada aktivitas kelompok melalui indikator-indikator berikut ini: (1) memperhatikan apa yang disampaikan guru, (2) bertanya kepada guru/teman, (3) merespon pertanyaan guru/teman, (4) mengerjakan LKS yang diberikan guru, (5) bekerjasama dalam kelompok, (6) mendiskusikan masalah, (7) bertukar pendapat antar teman dalam kelompok, (8) mempresentasikan hasil kerja kelompok, (9) berpartisipasi dalam membuat kesimpulan, dan (10) memanfaatkan sumber belajar. Perolehan skor kelompok kemudian dikatagorikan sebagai berikut : (1) kurang aktif (skor 1-10), cukup aktif (skor 11-20), (3) (skor 21-30), dan sangat aktif (skor 3140). Setelah dianalisis hasil observasi keaktifan belajar siswa dapat dilihat pada tabel 3 berikut ini.

Tabel 3. Analisis Keaktifan Pada Siklus I (S1)

\begin{tabular}{clccc}
\hline No & $\begin{array}{c}\text { Nama } \\
\text { Kelompok }\end{array}$ & $\begin{array}{c}\text { Jumla } \\
\text { h Skor }\end{array}$ & Katagori & $\begin{array}{c}\text { Keteranga } \\
\text { n }\end{array}$ \\
\hline 1. & Grup A & 31 & $\begin{array}{c}\text { Sangat } \\
\text { aktif }\end{array}$ & \\
2. & Grup B & 24 & Aktif & \\
3. & Grup C & 26 & Aktif & \\
4. & Grup D & 28 & Aktif & \\
5. & Grup E & 25 & Aktif & \\
6. & Grup F & 21 & Aktif & \\
\hline
\end{tabular}

b. Data Pengamatan Hasil Belajar

Data hasil belajar siklus I diperoleh dari hasil penilaian ulangan harian yang dilaksanakan pada akhir siklus I. Setelah dianalisis hasilnya tampak pada tabel 4 berikut ini.

Tabel 4. Analisis Hasil Belajar Pada Siklus I (S1)

\begin{tabular}{clll}
\hline No & \multicolumn{1}{c}{ Aspek Analisis } & \multicolumn{1}{c}{$\begin{array}{c}\text { Hasil } \\
\text { Analisis }\end{array}$} & $\begin{array}{c}\text { Keteranga } \\
\text { n }\end{array}$ \\
\hline 1. & Jumlah nilai & 2.238 & \\
2. & Nilai tertinggi & 98 & \\
3. & Nilai terendah & 55 & \\
4. & Rata-rata & 74.77 & Belum \\
& & & tuntas
\end{tabular}




\begin{tabular}{llll} 
5. & Daya serap & $74.77 \%$ & $\begin{array}{l}\text { Belum } \\
\text { tuntas }\end{array}$ \\
6. & Stándar deviasi & 11.45 & \\
7. & Ketuntasan belajar & $53 \%$ & $\begin{array}{l}\text { Belum } \\
\text { tuntas }\end{array}$ \\
8. & Jumlah siswa yang tuntas & 16 & \\
9. & $\begin{array}{l}\text { Jumlah siswa yang tidak } \\
\text { tuntas }\end{array}$ & 14 & \\
\hline
\end{tabular}

4. Refleksi Tindakan (Reflection)

a. Keaktifan Belajar

Berdasarkan análisis hasil observasi keaktifan kelompok seperti terlihat dalam tabel 3, dapat diketahui bahwa ada lima kelompok dalam katagori aktif, dan satu kelompok dalam katagori sangat aktif. Jika dibandingkan dengan hasil análisis angket keaktifan siswa pada kondisi awal, berarti beluam ada yang signifikan pada siklus I ini.

b. Hasil Belajar

Refleksi hasil belajar siklus I dilakukan dengan menggunakan análisis diskriptif komparatif, yaitu mengkomparasikan atau membandingkan hasil pre-test pada kondisi awal dengan hasil ulangan harian pada akhir siklus I seperti terlihat dalam tabel 5 berikut ini.

Tabel 5. Perbandingan Hasil Belajar Pada Kondisi Awal (dan Siklus I

\begin{tabular}{clllc}
\hline No. & \multicolumn{1}{c}{ Aspek Analisis } & \multicolumn{1}{c}{ N.0 } & \multicolumn{1}{c}{ N. SI } & Keterangan \\
\hline 1. & Jumlah nilai & 1.570 & 2.238 & Naik \\
2. & Nilai tertinggi & 90 & 98 & Naik \\
3. & Nilai terendah & 30 & 55 & Naik \\
4. & Rata-rata & 52.33 & 74.77 & Naik \\
5. & Daya serap & $52.33 \%$ & $74.77 \%$ & Naik \\
6. & Stándar deviasi & 16.95 & 11.45 & Turun \\
7. & Ketuntasan belajar & $9.38 \%$ & $53 \%$ & Naik \\
8. & Jumlah siswa yang tuntas & 3 & 16 & Naik \\
9. & Jumlah siswa yang tidak & 27 & 14 & Turun \\
& tuntas & & & \\
\hline
\end{tabular}

Dari Tabel 5 tersebut di atas dapat diketahui bahwa nilai rata-rata naik sebesar $43 \%$ dari 53.33 menjadi 74.77. Nilai tertinggi naik sebesar $9 \%$ dari 90 menjadi 98 . Nilai terendah naik $83 \%$ dari 30 menjadi 55. Jumlah siswa yang mencapai KKM juga naik sebesar $43 \%$ dari 3 orang menjadi 16. Dengan demikian dapat diambil kesimpulan sementara bahwa secara umum hasil belajar pada siklus I ini mengalami peningkatan, akan tetapi indikator keberhasilan belum tercapai, karena nilai rata-rata baru mencapai 74.77 masih di bawah KKM 75 dan prosentase pencapaian KKM baru mencapai $53 \%$ masih di bawah $85 \%$. Oleh karena itu peneliti bersama teman sejawat memandang perlu untuk melanjutkan pada siklus II, dengan memperbaiki RPP menggunakan modek kooperatif Jigsaw yang dikembangkan oleh Slavin, dkk.

\section{Deskripsi Data Hasil Siklus II}

1. Perencanaan Tindakan (Planning)

Pada tahap ini peneliti melakukan kegiatan sebagai berikut.

a. Merencanakan Rencana Pelaksanaan Pembelajaran (RPP) dengan model pembelajaran koopertif Jigsaw tipe Slavin, dkk. 


\section{Vol. 1 No. 4 November 2021 e-ISSN : 2775-2593 | p-ISSN : 2775-2585}

b. Membuat instrument penelitian untuk mengukur keaktifan belajar siswa berupa lembar observasi, angket dan alat pendokumentasian kegiatan.

c. Membuat instrumen penilaian hasil belajar berupa kisi-kisi dan lembar soal ulangan harian, kunci jawaban dan pedoman penilaian.

2. Pelaksanaan Tindakan (Acting)

Proses pembelajaran pada siklus II merupakan pembelajaran pada materi tentang Sistem Pemerintahan Indonesia dan Peran Lembaga Pemegang Kedaulatan Rakyat, yang dilaksanakan selama tiga kali pertemuan (6x40 menit). Pelaksanaan pembelajaran sesuai dengan model kooperatif Jigsaw tipe Slavin, dkk dengan langkah-langkah sebagai berikut.
a. Orientasi
b. Pengelompokan
c. Pembentukan dan pembinaan kelompok ahli (expert)
d. Diskusi (pemaparan) kelompok ahli dalam grup
e. Tes (penilaian)
f. Pengakuan kelompok

3. Pengamatan Tindakan (Observing)

a. Data Pengamatan Keaktifan

Pengamatan (observasi) keaktifan siswa pada proses pembelajaran siklus II juga ditekankan pada aktivitas kelompok melalui indikator-indikator seperti pada siklus I, setelah dianalisis hasilnya tampak pada tabel 6 berikut ini.

Tabel 6. Analisis Keaktifan Pada Siklus II

\begin{tabular}{|c|c|c|c|c|}
\hline $\begin{array}{c}\text { No } \\
\text {. }\end{array}$ & $\begin{array}{c}\text { Nama } \\
\text { Kelompok }\end{array}$ & $\begin{array}{l}\text { Jumla } \\
\text { h Skor }\end{array}$ & Katagori & $\begin{array}{c}\text { Keteranga } \\
\text { n }\end{array}$ \\
\hline 1. & Grup A & 34 & $\begin{array}{l}\text { Sangat } \\
\text { aktif }\end{array}$ & \\
\hline 2. & Grup B & 30 & Aktif & \\
\hline 3. & Grup C & 31 & $\begin{array}{l}\text { Sangat } \\
\text { aktif }\end{array}$ & \\
\hline 4. & Grup D & 34 & $\begin{array}{l}\text { Sangat } \\
\text { aktif }\end{array}$ & \\
\hline 5. & Grup E & 33 & $\begin{array}{l}\text { Sangat } \\
\text { aktif }\end{array}$ & \\
\hline 6. & Grup F & 34 & $\begin{array}{l}\text { Sangat } \\
\text { aktif }\end{array}$ & \\
\hline
\end{tabular}

b. Data Pengamatan Hasil Belajar

Data hasil belajar pada siklus II diperoleh dari hasil ulangan harian diakhir siklus II, setelah dianalisis dapat dilihat pada tabel 7 berikut ini.

Tabel 7. Analisis Hasil Belajar Pada Siklus II (SII)

\begin{tabular}{clll}
\hline No & \multicolumn{1}{c}{ Aspek Analisis } & \multicolumn{1}{c}{$\begin{array}{c}\text { Hasil } \\
\text { Analisis }\end{array}$} & $\begin{array}{c}\text { Keteranga } \\
\text { n }\end{array}$ \\
\hline 1. & Jumlah nilai & 2.415 & \\
2. & Nilai tertinggi & 100 & \\
3. & Nilai terendah & 55 & \\
4. & Rata-rata & 80.5 & Tuntas \\
5. & Daya serap & $80.5 \%$ & Tuntas \\
6. & Stándar deviasi & 10.29 & \\
7. & Ketuntasan belajar & $76.7 \%$ & Belum \\
8. & Jumlah siswa yang tuntas & 23 & tuntas
\end{tabular}


4. Refleksi Tindakan (Reflection)

a. Refleksi Keaktifan Belajar

Berdasarkan tabel 6 dapat diketahui bahwa ada lima kelompok dalam katagori sangat aktif, dan satu kelompok dalam katagori aktif. Jika dibandingkan dengan hasil análisis siklus I berarti suda hada peningkatan keaktifan yang signifikan pada siklus II.

b. Refleksi Hasil Belajar

Refleksi hasil belajar pada siklus II dilakukan dengan menggunakan teknik análisis deskripstif komparatif, yaitu mengkomparasikan/membandingkan antara hasil ulangan harian pada akhir siklus I dengan ulangan harian pada akhir siklus II, seperti terlihat pada tabel 8 berikut ini.

Tabel 8. Perbandingan Hasil Belajar Siklus I dan Siklus II

\begin{tabular}{clllc}
\hline No. & \multicolumn{1}{c}{ Aspek Analisis } & \multicolumn{1}{c}{ N. SI } & \multicolumn{1}{c}{ N. SII } & Keterangan \\
\hline 1. & Jumlah nilai & 2.238 & 2.415 & Naik \\
2. & Nilai tertinggi & 98 & 100 & Naik \\
3. & Nilai terendah & 55 & 55 & Tetap \\
4. & Rata-rata & 74.77 & 80.5 & Naik \\
5. & Daya serap & $74.77 \%$ & $80.5 \%$ & Naik \\
6. & Stándar deviasi & 11.45 & 10.29 & Turun \\
7. & Ketuntasan belajar & $53 \%$ & $76.7 \%$ & Naik \\
8. & Jumlah siswa yang tuntas & 16 & 23 & Naik \\
9. & Jumlah siswa yang tidak & 14 & 7 & Turun \\
& tuntas & & & \\
\hline
\end{tabular}

Dari tabel 8 di atas dapat diketahui bahwa nilai rata-rata naik sebesar 8\% dari 74.6 menjadi 80.5. Nilai tertinggi naik sebesar 2\% dari 98 menjadi 100. Nilai tertendah tetap. Jumlah siswa yang mencapai KKM (tuntas) juga naik sebsar 44\% dari 16 orang menjadi 23 orang. Dengan demikian dapat disimpulkan sementara bahwa hasil belajar pada siklus II ini mengalami peningkatan, akan tetapi indikator keberhasilan penelitian ini belum tercapai, karena cakupan materi pada siklus II luas dan sulit, sehingga prosentase pencapaian KKM baru mencapai 76.7\% masih di bawah $85 \%$. Oleh karena itu berdasarkan hasil diskusi dengan teman sejawat, peneliti memandang perlu melanjutkan penelitian tindakan kelas ini pada siklus III dengan memperbaiki RPP dengan menggunakan model Jigsaw yang dikembangkan oleh Slavin, dkk.

\section{Deskripsi Data Hasil Siklus III}

1. Perencanaan Tindakan (Planning

Pada tahap ini peneliti melakukan kegiatan sebagai berikut.

a. Merancang RPP dengan mpdel pembelajaran kooperatif tipe Jigsaw yang dikembangkan oleh Slavin, dkk.

b. Membuat instrumen penelitian untuk mengukur keaktifan belajar siswa berupa lembar observasi, angket dan alat pendokumentasian kegiatan.

c. Membuat instrumen penilaian hasil belajar berupa kisi-kisi dan lembar soal ulangan harian.

d. Menyiapkan lembar kerja kelompok serta alat dan bahan lain yang diperlukan dalam penelitian ini.

2. Pelaksanaan Tindakan (Acting) 
Vol. 1 No. 4 November 2021 e-ISSN : 2775-2593 | p-ISSN : 2775-2585

Proses pembelajaran pada siklus III dilaksanakan pada materi Menunjukkan Sikap Positif terhadap Kedaulatan Rakyat dalam Sistem Pemerintahan Indonesia, selama dua kali pertemuan (4 x 40 menit). Adapun langkah-langkah pembelajaran dengan model kooperatif Jigsaw tipe Slavin, dkk adalah sebagai berikut.
a. Orientasi
b. Pengelompokan
c. Pembentukan dan pembinaan kelompok expert (ahli)
d. Diskusi (pemaparan) kelompok ahli dalam group
e. Tes (penilaian)
f. Pengakuan kelompok

3. Pengamatan Tindakan (Observing)

a. Keaktifan Belajar

Pengamatan (observasi) keaktifan siswa pada proses pembelajaran juga ditekankan pada aktifitas kelompok melalui indikator-indikatoryang ditetapkan dalam penelitian ini. Hasil obeservasi keaktifan belajar siswa setelah dianalisis tampak pada tabel 9 berikut ini.

Tabel 9. Analisis Keaktifan Pada Siklus II

\begin{tabular}{|c|c|c|c|c|}
\hline $\begin{array}{c}\text { No } \\
\text {. }\end{array}$ & $\begin{array}{c}\text { Nama } \\
\text { Kelompok }\end{array}$ & $\begin{array}{l}\text { Jumla } \\
\text { h Skor }\end{array}$ & Katagori & $\begin{array}{c}\text { Keteranga } \\
\mathbf{n}\end{array}$ \\
\hline 1. & Grup A & 33 & $\begin{array}{c}\text { Sangat } \\
\text { Aktif }\end{array}$ & \\
\hline 2. & Grup B & 32 & $\begin{array}{c}\text { Sangat } \\
\text { aktif }\end{array}$ & \\
\hline 3. & Grup C & 34 & $\begin{array}{l}\text { Sangat } \\
\text { aktif }\end{array}$ & \\
\hline 4. & Grup D & 33 & $\begin{array}{l}\text { Sangat } \\
\text { aktif }\end{array}$ & \\
\hline 5. & Grup E & 33 & $\begin{array}{l}\text { Sangat } \\
\text { aktif }\end{array}$ & \\
\hline 6. & Grup F & 32 & $\begin{array}{c}\text { Sangat } \\
\text { aktif }\end{array}$ & \\
\hline
\end{tabular}

Selain melalui observasi, pada akhir siklus III ini peneliti juga melakukan pengukuran variabel keaktifan belajar siswa melalui angket. Hal ini dimaksudkan untuk menjamin keakuratan data dalam penelitian ini. Adapun hasil análisis angket keaktifan siswa dapat dilihat dalam tabel 10 berikut ini.

Tabel 10. Perbandingan Keaktifan Belajar Pada Kondisi Awal dan Siklus III

\begin{tabular}{ccccc}
\hline Uraian & $\begin{array}{c}\text { Kondisi } \\
\text { Awal }\end{array}$ & Siklus III & Jumlah & Rata-Rata \\
& 2203 & 2373 & 4576 & 2288 \\
Jumlah & 73.43 & 79.10 & 152.53 & 76.27 \\
Rata-rata & & & & \\
\hline
\end{tabular}

b. Hasil Belajar

Data hasil belajar siswa diperoleh dari tes ulangan harian yang dilaksanakan pada akhir siklus III. Setelah dianalisis hasilnya tampak pada tabel 11 berikut ini.

Tabel 11. Analisis Hasil Belajar Pada Siklus II (SII)

\begin{tabular}{cccc}
\hline No & Aspek Analisis & $\begin{array}{c}\text { Hasil } \\
\text { Analisis }\end{array}$ & Keterangan \\
\hline 1. & Jumlah nilai & 2.620
\end{tabular}


Vol. 1 No. 4 November 2021 e-ISSN : 2775-2593 | p-ISSN : 2775-2585

2. Nilai tertinggi

3. Nilai terendah

4. Rata-rata

5. Daya serap

6. Stándar deviasi

7. Ketuntasan belajar

8. Jumlah siswa yang tuntas

Jumlah siswa yang tidak tuntas
100

55

$87.33 \quad$ Tuntas

$87.33 \% \quad$ Tuntas

11.50

93.33\% Tuntas

28

2

4. Refleksi Tindakan (Reflection)

a. Keaktifan Belajar

Dari data observasi seperti dalam tabel 9 dan 10 di atas menunjukkan bahwa tingkat keaktifan belajar siswa kelas VIIIA mengalami peningkatan yang siginifikan dari katagori aktif pada kondisi awal menjadi sangat aktif pada akhir siklus III.

b. Hasil Belajar

Refleksi hasil belajar pada siklus III ini dilakukan dengan menggunakan análisis diskriptif komparatif, yaitu mengkomparasikan/membandingkan hasil ulangan harian pada akhir siklus II dengan hasil ulangan harian pada akhir siklus III seperti terlihat pada tabel 12 berikut ini.

Tabel 12. Perbandingan Hasil Belajar Siklus II dan Siklus III

\begin{tabular}{cllll}
\hline No. & \multicolumn{1}{c}{ Aspek Analisis } & \multicolumn{1}{c}{ N. S II } & N. S III & Keterangan \\
\hline 1. & Jumlah nilai & 2.415 & 2.620 & Naik \\
2. & Nilai tertinggi & 100 & 100 & Naik \\
3. & Nilai terendah & 55 & 55 & Tetap \\
4. & Rata-rata & 80.5 & 87.33 & Naik \\
5. & Daya serap & $80.5 \%$ & $87.33 \%$ & Naik \\
6. & Stándar deviasi & 10.29 & 11.50 & Turun \\
7. & Ketuntasan belajar & $76.7 \%$ & $93.33 \%$ & Naik \\
8. & Jumlah siswa yang tuntas & 23 & 28 & Naik \\
9. & Jumlah siswa yang tidak & 7 & 2 & Turun \\
& tuntas & & &
\end{tabular}

Dari tabel 12 di atas dapat diketahui bahwa nilai rata-rata naik sebesar $9 \%$ dari 80.5 menjadi 87.33. Nilai tertinggi tetap 100. Nilai terendah juga tetap sebesar 55. Jumlah siswa yang mencapai KKM naik sebesar $22 \%$ dari 23 orang menjadi 28 orang. Dengan demikian dapat diambil kesimpulan bahwa secara umum hasil belajar pada siklus III mengalami peningkatan yang signifikan, indikator kinerja dalam penelitian ini sudah tercapai, yaitu rata-rata sudah di atas KKM 75, dan prosentase pencapaian KKM sudah di atas $85 \%$. Dengan demikian penelitian ini dihentikan pada siklus III.

\section{Pembahasan}

1. Keaktifan Siswa

Menurut kamus Besar bahasa Indonesia, kata keaktifan berasal dari kata dasar aktif, yang artinya "giat (bekerja, berusaha)", kemudian mendapat imbuhan ke-an menjadi keaktifan yang berarti "kegiatan, kesibukan" (Depdinas, 2008:31).

Pada saat guru mengajar harus mengusahakan agar peserta didiknya dapat aktif baik secara jasmani maupun rokhani. Menurut Sriyono, dkk dalam Mayasa (2012), keaktifan jasmani maupun rokhani meliputi: (1) keaktifan indra : murid harus dirangsang adar dapat menggunakan alat inderanya sebaik mungkin, (2) keaktifan akal : akal anak-anak aktif atau diaktifkan untuk memecahkan masalah, (3) keaktifan ingatan: pada waktu mengajar anak harus 


\section{Vol. 1 No. 4 November 2021 e-ISSN : 2775-2593 | p-ISSN : 2775-2585}

aktif menerima bahan pengajaran yang disampaikan oleh guru dan menyimpannya dalam otak, dan (4) keaktifan emosi: anak hendaklah senantiasa mencintai pelajarannya.

Dari definisi di atas, maka dapat disimpulkan bahwa keaktifan siswa adalah perana aktif siswa baik secara jasmani maupun rokhani dalam kegiatan pembelajaran di kelas. Keaktifan belajar yang dilakukan oleh siswa sangat mempengaruhi hasil belajar siswa tersebut. Hasil belajar adalah kemampuan-kemampuan yang dimiliki siswa setelah menerima pelajaran (Sudjana:22). sebab siswa yang aktif dalam kegiatan pembelajaran akan mampu menangkap dan menyimpan materi yang diajarkan dengan lebih optimal.

Pembahasan keaktifan belajar siswa pada penelitian ini, didasarkan pada hasil pengamatan dan refleksi pada kondisi awal, siklus I, Siklus II, dan Siklus III. Data dari hasil pengamatan dan refleksi tersebut menunjukkan bahwa keaktifan siswa kelas VIIIA meningkat dari katagori aktif menjadi sangat aktif di akhir siklus III. Data ini diperkuat oleh foto-foto dokumentasi kegiatan dan hasil análisis angket pada akhir siklus III. Peningkatan keaktifan siswa kelas VIII A berdasarkan análisis angket pada kondisi awal dengan akhir siklus III dapat dilihat pada gambar 1 berikut ini.

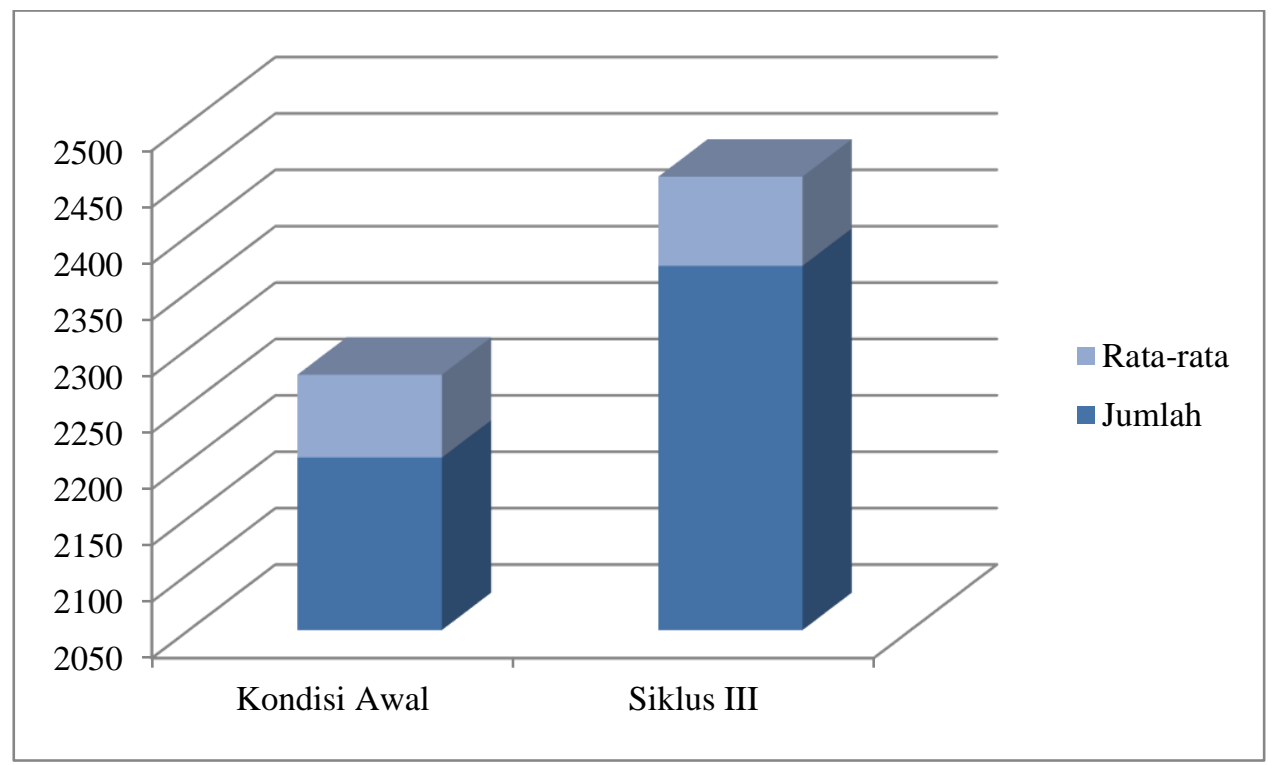

Gambar 1. Peningkatan Keaktifan Siswa

2. Hasil Belajar

Hasil belajar adalah kemampuan-kemampuan yang dimiliki siswa setelah menerima pelajaran (Sudjana:22). Hasil belajar disebut juga prestasi belajar. Menurut Sutratinah (2001:43), prestasi belajar adalah penilaian hasil usaha kegiatan yang dinyatakan dalam bentuk simbol, angka, huruf, maupun kalimat yang dapat mencerminkan hasil yang sudah dicapai oleh anak dalam periode tertentu. Simbol, angka, huruf maupun kalimat sebenarnya hanya merupakan visualisasi hasil belajar, karena hasil belajar yang sesungguhnya merupakan performaaansi maksimal subjek dalam menguasai bahan atau materi yang diajarkan"(Azwar, dalam Martiyono:7).

Berdasarkan beberapa pengetian di atas dapat disimpulkan bahwa hasil belajar atau prestasi belajar adalah keseluruhan performansi atau pencapaian kompetensi atau kemampuankemampuan yang dimiliki siswa setelah menerima pengalaman belajarnya, yang dinyatakan dalam bentuk simbol, angka, huruf, maupun kalimat.

Pembahasan hasil belajar pada penelitian tindakan kelas ini didasarkan pada data-data hasil penilaian awal yang dilaksanakan melalui pre-test (N0), nilai ulangan harian siklus I, II, dan III. Adapun perbandingan data hasil belajar tersebut dapat di lihat pada tabel berikut ini. 
EDUCATIONAL : Jurnal Inovasi Pendidikan dan Pengajaran

Vol. 1 No. 4 November 2021 e-ISSN : 2775-2593 | p-ISSN : 2775-2585

Tabel 13. Perbandingan Hasil Belajar Para Siklus, Siklus I, Siklus II dan Siklus III

\begin{tabular}{lllllll}
\hline No. & \multicolumn{1}{c}{ Aspek Analisis } & No & N. SI & N. SII & $\begin{array}{c}\text { N. } \\
\text { SIII }\end{array}$ & $\begin{array}{c}\text { Keteranga } \\
\text { n }\end{array}$ \\
\hline 1. & Jumlah nilai & 1.570 & 2.238 & 2.415 & 2.620 & Naik \\
2. & Nilai tertinggi & 90 & 98 & 100 & 100 & Naik \\
3. & Nilai terendah & 30 & 55 & 55 & 55 & Tetap \\
4. & Rata-rata & 52.33 & 74.77 & 80.5 & 87.33 & Naik \\
5. & Daya serap & 52.33 & 74.77 & $80.5 \%$ & 87.33 & Naik \\
6. & Stándar deviasi & $\%$ & $\%$ & & $\%$ & \\
7. & Ketuntasan belajar & 16.95 & 11.45 & 10.29 & 11.50 & Turun \\
8. & Jumlah siswa yang tuntas & 3 & 16 & 23 & 28 & Naik \\
9. & Jumlah siswa yang tidak & 27 & 14 & 7 & 2 & Turun \\
\hline
\end{tabular}

Dalam bentuk grafik peningkatan hasil belajar dari kondisi awal, siklus I, siklus II, dan siklus III tampak pada gambar 2 berikut ini.

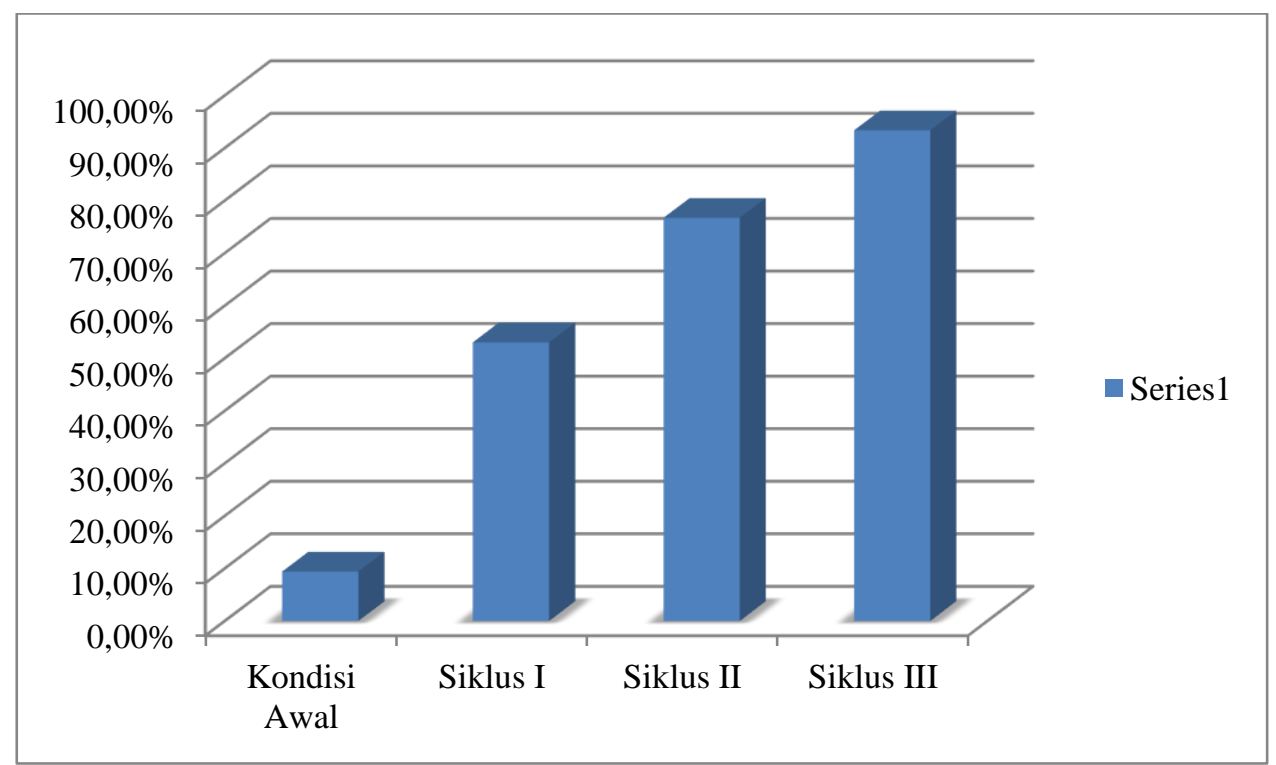

Gambar 2. Grafik Prosentase Ketuntasan Belajar Antar Siklus

Berdasarkan tabel 13 dan gambar 2 menunjukkan bahwa penelitian tindakan kelas yang dilaksanakan dalam tiga siklus dengan menggunakan model pembelajaran kooperatif Jigsaw dapat meningkatkan hasil belajar Pkn. Hasil belajar PKn meningkat sebesar $60 \%$ dari kondisi awal ke siklus III. Rata-rata hasil belajar meningkat dari siklus ke siklus, dari kondisi awal sebesar 52.22 menjadi 74.77 pada siklus I, 80.5 pada siklus II, dan 87.33 pada siklus III. Ketuntasan KKM dari siklus ke siklus juga mengalami peningkatan dari kondisi awal sebesar 9.38\% menjadi 53\% pada siklus I, 76.7\% pada siklus II dan $93.33 \%$ pada siklus III. Peningkatan keaktifan dan hasil belajar PKn ini disebabkan karena pelaksanaan pembelajaran dengan menggunakan model kooperatif Jigsaw semakin efektif, menarik dan menyenangkan sehingga memotivasi siswa untuk lebih giat belajar lagi. Hal lain yang dapat menumbuhkan semangat siswa untuk belajar lebih giat lagi adalah pada akhir pembelajaran guru memberikan reward berupa hadiah bagi setiap kelompok yang hasil belajarnya selalu meningkat.

Keberhasilan penelitian tindakan kelas ini sejalan dengan hasil penelitian Jhonson (dalam Rusman, 2011:219) yang menunjukkan bahwa interaksi kooperatif memiliki berbagai pengaruh positif terhadap perkembangan anak. pengaruh positif tersebut adalah sebagai berikut: 


\section{Vol. 1 No. 4 November 2021 e-ISSN : 2775-2593 | p-ISSN : 2775-2585}

(1) meningkatkan hasil belajar, (2) meningkatkan daya ingat, (3) dapat digunakan untuk mencapai taraf penalaran tingkat tinggi, (4) mendorong tumbuhnya motivasi intrinsik (kesadaran individu), (5) meningkatkan hubungan antar manusia yang heterogen, (6) meningkatkan sikap anak yang positif terhadap guru dan sekolah, (7) meningkatkan harga diri anak, (8) meningkatkan perilaku penyesuaian sosial yang positif, dan (8) meningkatkan ketrampilan hidup bergotong-royong.

Arta (2021:19) juga menyatakan bahwa model pembelajaran kooperatif Jigsaw dapat meningkatkan aktivitas dan hasil belajar IPS pada siswa kelas V SD Negeri 4 Tenganan. Menurutnya dalam menggunakan model pembelajaran kooperatif Jigsaw perlu dilengkapi dengan LKS dan sarana lain yang diperlukan, sehingga proses pembelajaran akan berpusat pada siswa, menyenangkan dan menjadi lebih bermakna.

Dengan demikian dapat disimpulkan bahwa model pembelajaran kooperatif Jigsaw dapat dijadikan sebagai salah satu solusi atau alternatif untuk mengatasi permasalahan keaktifan dan hasil belajar siswa dalam materi pelajaran apapun, dan salah satunya adalah mata pelajaran Pendidikan Kewarganegaraan (PKn).

\section{KESIMPULAN}

Berdasarkan data yang diperoleh dari pengalaman secara empiris dan hasil analisisnya pada bab IV laporan hasil penelitian tindakan kelas ini serta didukung oleh kajian teoritis yang dikemukakan dalam Bab II laporan penelitian tindakan kelas ini maka dapat disimpulkan bahwa.

1. Melalui model pembelajaran kooperatif Jigsaw dapat meningkatkan keaktifan belajar siswa kelas VIIIA pada mata pelajaran PKn. Implikasi dari penelitian ini adalah penggunaan model kooperatif Jigsaw yang dikelola secara baik akan dapat meningkatkan keaktifan belajar siswa pada mata pelajaran PKn pada khususnya dan keaktifan belajar siswa pada mata pelajaran lain pada umumnya.

2. Melalui model pembelajaran kooperatif Jigsaw dapat meningkatkan hasil belajar siswa kelas VIIIA pada mata pelajaran PKn. Implikasinya adalah jika model pembelajaran ini dilaksanakan di sekolah dengan pengelolaan yang baik maka akan dapat meningkatkan hasil belajar PKn pada khususnya dan pada mata pelajaran lain pada umumnya.

\section{DAFTAR PUSTAKA}

Arta, I Made. (2017). Penerapan Model Pembelajaran Kooperatif Tipe Jigsaw Untuk Meningkatkan Hasil Belajar IPS Siswa Kelas V SD Negeri 4 Tenganan Semester II Tahun Pelajaran 2018/2019. E-Jurnal Inovasi Penelitian Tindakan Kelas dan Sekolah, Vol 1. No.1 Juli 2021 e-ISSN : 2798-5733 P-ISSN : 2798-5741

BNSP. (2007). Panduan Penilaian Kelompok Mata Pelajaran Kewarganegaraan dan Kepribadian. Jakarta: Rajawali.

Bambang Purnomo. (2013). Upaya Meningkatkan Hasil Belajar Menulis Descriptive Text Bahasa Inggris dan Keaktifan Siswa Menggunakan The Nearest Neighborhood Media Melalui Metode Bangmogi Siswa Kelas 7B Sekolah Menengah Pertama Negeri 1 Kebumen. Laporan Penilitian Tindakan Kelas.

Depdiknas. (2003). Pelayanan Profesional Kurikulum 2004 Kegiatan Belajar Mengajar Yang Efektif. Jakarta: Depdiknas.

Depdiknas. (2006). Pedoman Pengembangan Silabus Mata Pelajaran Pendidikan Kewarganegaraan SMP. Jakarta: Depdiknas.

Depdiknas. (2003). Undang-Undang Negara Republik Indonesia Nomor 20 Tahun 2003 Tentang Sistem Pendidikan Nasional. Jakarta: Depdiknas.

Depdiknas. (2008). Kamus Besar Bahasa Indonesia. Jakarta: Depdiknas.

E. Mulyasa. (2009). Stándar Kompetensi dan Sertifikasi Guru. Bandung: Rosda.

Erna. (2009). Indikator Keaktifan Siswa. http://ardhana12.wordpress. 20-01-2009.

Harun Rasyid dan Mansur. (2008). Seri Pembelajaran Efektif : Penilaian Hasil Belajar. 
Bandung: CV Wacana Prima.

Martiyono. (2012). Perencanaan Pembelajaran Suatu Pendekatan Praktis Berdasarkan KTSP Termasuk Model Tematik. Yogyakarta: Aswaja Pressindo.

M. Ngalim Purwanto. (1992). Psikologi Pendidikan. Jakarta: Debdikbud.

Martinis Yamin. (2007). Kiat Membelajarkan Siswa. Jakarta: Daung Persada Press dan Center for Learning Innovation (CLI).

Miftahul Huda. (2013). Model-Model Pengajaran Dan Pembelajaran Isu-Isu Metodis Dan Paradigma. Yogyakarta: Pustaka Pelajar.

Mulyadi. (2010). Bahan Paparan Permasalahan Dalam PTK. Semarang: Kemendiknas.

Nana Sudjana. (2009). Penilaian Hasil Proses Belajar Mengajar. Bandung: Rosda.

Nurhadi, Yasin, B., Senduk, A.G. 2004. Pembelajaran Kontekstual (Contextual Teaching and Learning/CTL) Dan Penerapannya dalam KBK. Malang: Universitas Negeri Malang.

Oumar Hamalik. (2007). Proses Belajar Mengajar. Bandung: Bumi Aksara.

Rochiati Wiriaatmadja. (2012). Metode Penelitian Tindakan Kelas Untuk Meningkatkan Kinerja Guru Dan Dosen. Bandung: PT. Remaja Rosdakarya.

Rusman. (2012). Seri Manejemen Sekolah Bermutu. Model-Model Pembelajaran Mengembangkan Profesionalisme Guru. Jakarta: PT Raja Grafindo Persada.

Saefusin Azwar. (2008). Penyusunan Skala Psikologi. Yogyakarta: Pustaka Pelajar.

Slameto. 1987. Belajar dan Faktor-Faktor Yang Mempengaruhinya. Jakarta: Bina Aksara.

Sukidin, Basrowi, Suranto. (2010). Manajemen Penelitian Tindakan Kelas. Yogyakarta: Insan Cendekia.

Sutratinah Tirtonegoro. (2001). Anak Supernormal dan Program Pendidikannya. Jakarta: Bumi Aksara.

Trianto. (2009). Mendesain Model Pembelajaran Inovatif-Progresif: Konsep, Landasan, dan Implementasinya pada Kurikulum Tingkat Satuan Pendidikan (KTSP). Jakarta: Kencana Prenada Media Group.

Wina Sanjaya. (2008). Strategi Pembelajaran Berorientasi Estándar Proses Pendidikan. Jakarta: Kencana Prenada Media Group. 